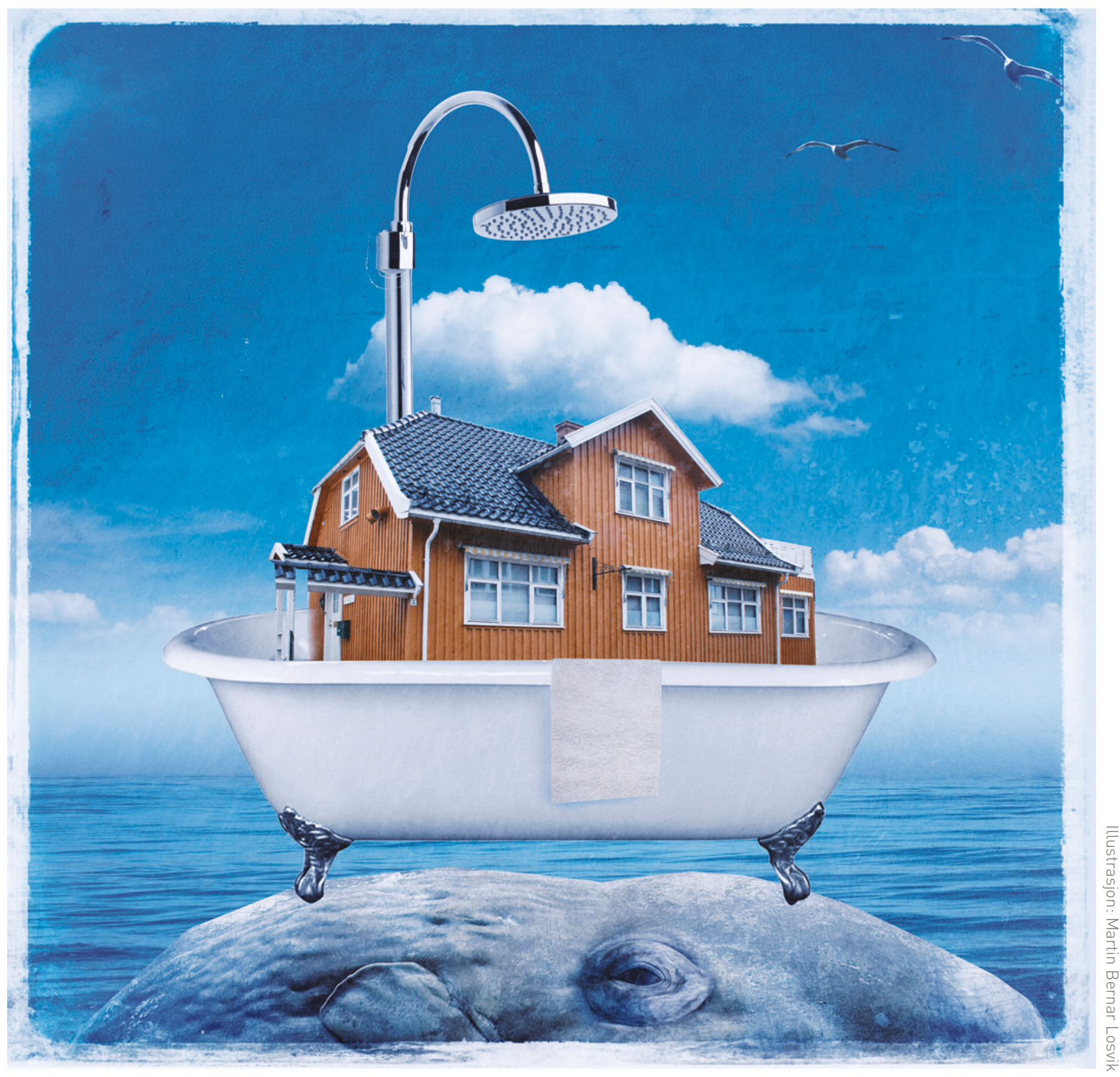

\title{
Legehuset Sandefjord
}

(i)

Sommerbyen Sandefjord i Vestfold har ca. 40000 innbyggere. På Legehuset i sentrum av byen, ikke langt fra Hvalfangstmuseet, arbeider to leger og tre helsesekretærer. 